\title{
Effect of different media on mycelium growth of Sclerotium rolfsii Sacc. invitro condition
}

\section{Prem Pandey ${ }^{1}$ and Shankar P. Gaire ${ }^{2}$}

\author{
${ }^{1}$ Agriculture and Forestry University (AFU), Rampur, Chitwan, Nepal \\ ${ }^{2}$ Texas A\&M AgriLife Research center, Beaumont, TX, U.S.A. \\ Corresponding author Email: pandeyprem73@gmail.com
}

\begin{abstract}
An invitro experiment was conducted to study the effect of different culture media on mycelial growth of Sclerotium rolfsii Sacc. in Plant pathology Laboratory of Agriculture and Forestry University, Nepal. The pathogenic isolate of $S$. rolfsii was isolated from symptomatic tomato and maintained in PDA. Seven different culture media viz. Potato Dextrose Agar (PDA), Chickpea Dextrose Agar (ChDA), Bean Dextrose Agar (BDA), Carrot Dextrose Agar (CDA), Papaya Dextrose Agar (PpDA), Czapek Dox Agar (CzDA) and Sabouraud's Dextrose Agar (SDA) were prepared and 5-mm diameter mycelial plugs from the margins of 3-days old S. rolfsiiculture was transfer in the middle of each media plate. The radial mycelial growth was measured at 2 days interval for 14 days. Chickpea Dextrose Agar (ChDA) had significantly higher mycelia growth, which was superior than Potato dextrose agar (PDA). Papaya fruit, carrot root, chickpea grain and bean grain can be the common cheap source of carbon in industrial development of culture media.
\end{abstract}

Keywords-Media, S. rolfsii, Mycelium, Carbon, isolate.

\section{INTRODUCTION}

Sclerotium rolfsiiSacc. is a necrotrophic soilborne plant pathogen forming sclerotia as a survival structure distributed worldwide. It causes various symptoms like seedling damping-off, root rot, collar rot, and stem rot in more than 500 plant species commonly legumes, crucifers, and cucurbits (Barnett and Hunter, 1972). Because of prolific growth of $S$. rolfsii and ability to produce persistent sclerotia, it is contributing in high degree of economic losses (Mahen et al., 1995). Under conducive conditions it can causes $55-95 \%$ mortality of the crop at seedling stage (Gurha and Dubey, 1982). Infection on plants by the pathogen is governed and triggered by the initial recognition phenomenon. Establishment of the pathogen in host depends upon some kind of similarity between two interacting partners (De Vay \& Adler, 1976).

The capacity of fungi to utilize the available nutrients, of which carbohydrates are the major ones determine the ability of fungi to grow in different media. So it was observed that the growth rate varies with different carbon sources. Fungal media containing high carbohydrate source, nitrogen source is required for the growth of fungi at $\mathrm{pH}$ range of 5 to 6 , and a temperature range from 15 to $37^{\circ} \mathrm{C}$. Fungal culture media are natural and synthetic. Natural media are composed of natural substrates like potato dextrose agar, V-8 juice agaretc whereas synthetic media contain defined amounts of carbohydrates, nitrogen, and vitamin sources (eg: Czapek-Dox medium).

Potato dextrose agar (PDA) is most commonly used natural media for the culture of fungi. Most lab used media are not cost effective at a large-scale, so industrialists have started to use several common cheap sources of carbon. So, the objective of this research was to identify alternative natural fungal media using substrate with cheap source of carbon.

\section{MATERIALS AND MIETHODS}

\section{Media preparation}

Five natural media: Potato Dextrose Agar(PDA), Chickpea Dextrose Agar(ChDA), Carrot Dextrose Agar(CDA), Bean Dextrose Agar(BDA), Papaya Dextrose Agar(PpDA) and two synthetic media: Saubourds Dextrose Agar(SDA),Czepadox Dextrose Agar(CzDA) were prepared. $200 \mathrm{~g}$ of potato pieces, chickpeagrains, carrot pieces, bean grains, papaya fruit pieceswere weighed individually for their respective media viz. PDA, ChDA, CDA, BDA, PpDArespectively and boiled in $500 \mathrm{ml}$ of water for 10 minutes and filtered with muslin cloths. We added $20 \mathrm{~g}$ of dextrose and $20 \mathrm{~g}$ of agar in each media and added distilled water to make the final volu me of $1000 \mathrm{ml}$. 
The synthetic media were prepared as manufactural instruction. SDA was prepared by mixing $40 \mathrm{~g}$ of dextrose, $10 \mathrm{~g}$ of Peptone and $15 \mathrm{~g}$ of Agar in $1000 \mathrm{ml}$ of distilled water and CzDA by $30 \mathrm{~g}$ of Sucrose, $2 \mathrm{~g}$ of sodium nitrate, $1 \mathrm{~g}$ of Dipotassium phosphate, $0.5 \mathrm{~g}$ of Magnesium sulphate, $0.5 \mathrm{~g}$ of Potassium chloride, $0.01 \mathrm{~g}$ of Ferrous nitrate, $15 \mathrm{~g}$ of agar in $1000 \mathrm{ml}$ of distilled water. The media were autoclaved for $121^{\circ} \mathrm{C}$ for 20 minutes at $15 \mathrm{psi}$ pressure.

Table 1: Composition of different natural culture media

\begin{tabular}{llllll}
\hline Ingredients & PDA & ChDA & PpDA & BDA & CDA \\
\hline Pieces/grain & $200 \mathrm{~g}$ & $200 \mathrm{~g}$ & $200 \mathrm{~g}$ & $200 \mathrm{~g}$ & $200 \mathrm{~g}$ \\
Dextrose & $20 \mathrm{~g}$ & $20 \mathrm{~g}$ & $20 \mathrm{~g}$ & $20 \mathrm{~g}$ & $20 \mathrm{~g}$ \\
Agar & $20 \mathrm{~g}$ & $20 \mathrm{~g}$ & $20 \mathrm{~g}$ & $20 \mathrm{~g}$ & $20 \mathrm{~g}$ \\
Distilled water & $1000 \mathrm{ml}$ & $1000 \mathrm{ml}$ & $1000 \mathrm{ml}$ & $1000 \mathrm{ml}$ & $1000 \mathrm{ml}$ \\
\hline
\end{tabular}

\section{Isolation of $S$. rolfsii}

The pathogen, $S$. rolfsii was isolated from the stems of infected to mato plants grown in Chitwan, Nepal by tissue segment method (Rangaswami and Mahadevan, 1999) onPDA. Small pieces of tissue of about $1 \mathrm{~cm}$ from infected collar region with some healthy tissue were cut with sterile blade. The pieces were surface sterilized with $1 \%$ sodium hypochlorite solution for 1 minute followed by three subsequent wash with sterilized distilled water. These pieces were kept onto PDA medium in Petri dishes. Plates were incubated at $27 \pm 2^{\circ} \mathrm{C}$ for 2 day. The pathogen was identified as $S$. rolfsii based on its mycelial and sclerotial characteristics (Barnett and Hunter, 1972).

\section{Experimental setup}

The experiment was conducted in Plant Pathology laboratory of Agriculture and Forestry University (AFU), Chit wan, Nepal. Approximately 20-ml of autoclaved med ia was poured in each petri plate (9-cm diameter). Each plate was inoculated with a 5-mm diameter mycelial plugs from the margins of 3-days old culture grown on PDA. Plates were then incubated at $27 \pm 2^{0} \mathrm{C}$ with 12 -hour photoperiod for two weeks. The radial mycelial growth was measured in every 2 days interval for 14 days. The experiment was replicated four times.

\section{Data analysis}

Analys is of variance (ANOVA) was conducted using R version 3.6.0. Significant differences between treatments were determined using a Duncan multiple range test $(\mathrm{DMRT})$ at $\mathrm{p}=0.05$.

\section{RESULTS AND DISCUSSION}

\section{Mycelial growth}

Although the mycelial growth of $S$. rolfsiin papaya dextrose agar was significantly lower than potato dextrose agar up to 6 days of incubation, the mycelial growth was at par in both growth media after 8-DAI (Table 2 ). In chickpea dextrose agar medium, the mycelial growth was consistently superior over the 14-DAI (Table 2). This result showed that chickpea dextrose agar, papaya dextrose agar and bean dextrose agar can be used as alternative nutrient source for the growth of $S$. rolfsii.

Since sugars are the principle constituents of papaya with total content of $48.3 \%$ sucrose, $29.8 \%$ glucose and 2\% fructose (Chan and Kwok, 1975; Gomez et al., 2006) and it also contains sodium, potassium, Magnesium, Calcium, Iron and other vitamins which encourages the growth of pathogen.

Chickpea contains on an average $23 \%$ of protein, $64 \%$ carbohydrate, $6 \%$ crude fibre and $3 \%$ ash. It also has high mineral content like phosphorous, calcium, magnesium, iron and zinc etc. these nutrients are capable of supporting fungal growth (Junakali AK et al., 2009).

Kan A et al. (2010) reported that chickpea has natural antibacterial activity against gram negative bacteria like Staphylococcus aureus, Bacillus substilis and Enterococcus faecalis. Hence the natural antibacterial property in Chickpea dextrose agar has additional benefits as media more selective for fungi and less prone to bacterial contamination. 
Table 2: Effect of different growth media on the mycelial growth of the pathogen S. rolfsiiSacc.

\begin{tabular}{llllllll}
\hline Treatments & 2 DAI & 4 DAI & 6 DAI & 8 DAI & 10 DAI & 12 DAI & 14 DAI \\
\hline Papaya dextrose agar & $1.25^{\mathrm{cd}}$ & $1.70^{\mathrm{d}}$ & $2.47^{\mathrm{cd}}$ & $3.22^{\mathrm{bd}}$ & $6.10^{\mathrm{b}}$ & $8.10^{\mathrm{a}}$ & $9.00^{\mathrm{a}}$ \\
Chickpea dextrose agar & $2.45^{\mathrm{a}}$ & $3.35^{\mathrm{a}}$ & $4.50^{\mathrm{a}}$ & $5.37^{\mathrm{a}}$ & $7.30^{\mathrm{a}}$ & $7.95^{\mathrm{a}}$ & $8.77^{\mathrm{ab}}$ \\
Potato dextrose agar & $2.17^{\mathrm{ab}}$ & $3.02^{\mathrm{ab}}$ & $3.50^{\mathrm{b}}$ & $3.97^{\mathrm{b}}$ & $5.52^{\mathrm{b}}$ & $7.35^{\mathrm{ab}}$ & $7.87^{\mathrm{abc}}$ \\
Bean dextrose agar & $1.75^{\mathrm{bc}}$ & $2.65^{\mathrm{bc}}$ & $3.32^{\mathrm{b}}$ & $3.80^{\mathrm{bc}}$ & $5.87^{\mathrm{b}}$ & $6.97^{\mathrm{b}}$ & $7.57^{\mathrm{bcd}}$ \\
Sabouraud dextrose agar & $1.05^{\mathrm{d}}$ & $1.62^{\mathrm{d}}$ & $2.10^{\mathrm{d}}$ & $2.65^{\mathrm{d}}$ & $4.45^{\mathrm{c}}$ & $6.12^{\mathrm{bc}}$ & $6.90^{\mathrm{cd}}$ \\
Carrot dextrose agar & $0.92^{\mathrm{d}}$ & $1.07^{\mathrm{e}}$ & $1.30^{\mathrm{e}}$ & $1.55^{\mathrm{e}}$ & $3.85^{\mathrm{c}}$ & $5.05^{\mathrm{cd}}$ & $6.47^{\mathrm{d}}$ \\
Czapek Dox Agar & $1.97^{\mathrm{ab}}$ & $2.32^{\mathrm{c}}$ & $2.95^{\mathrm{bc}}$ & $3.05^{\mathrm{cd}}$ & $3.82 \mathrm{c}$ & $4.20^{\mathrm{d}}$ & $4.55^{\mathrm{e}}$ \\
\hline F test & $* * *$ & $* * *$ & $* * *$ & $* * *$ & $* * *$ & $* * *$ & $* * *$ \\
SEM & 0.119 & 0.139 & 0.237 & 0.239 & 0.529 & 0.821 & 0.613 \\
LSD 0.001 & 0.025 & 0.027 & 0.035 & 0.035 & 0.053 & 0.066 & 0.052 \\
CV $(\%)$ & 20.8 & 16.6 & 16.9 & 14.5 & 13.7 & 13.8 & 10.7 \\
\hline
\end{tabular}

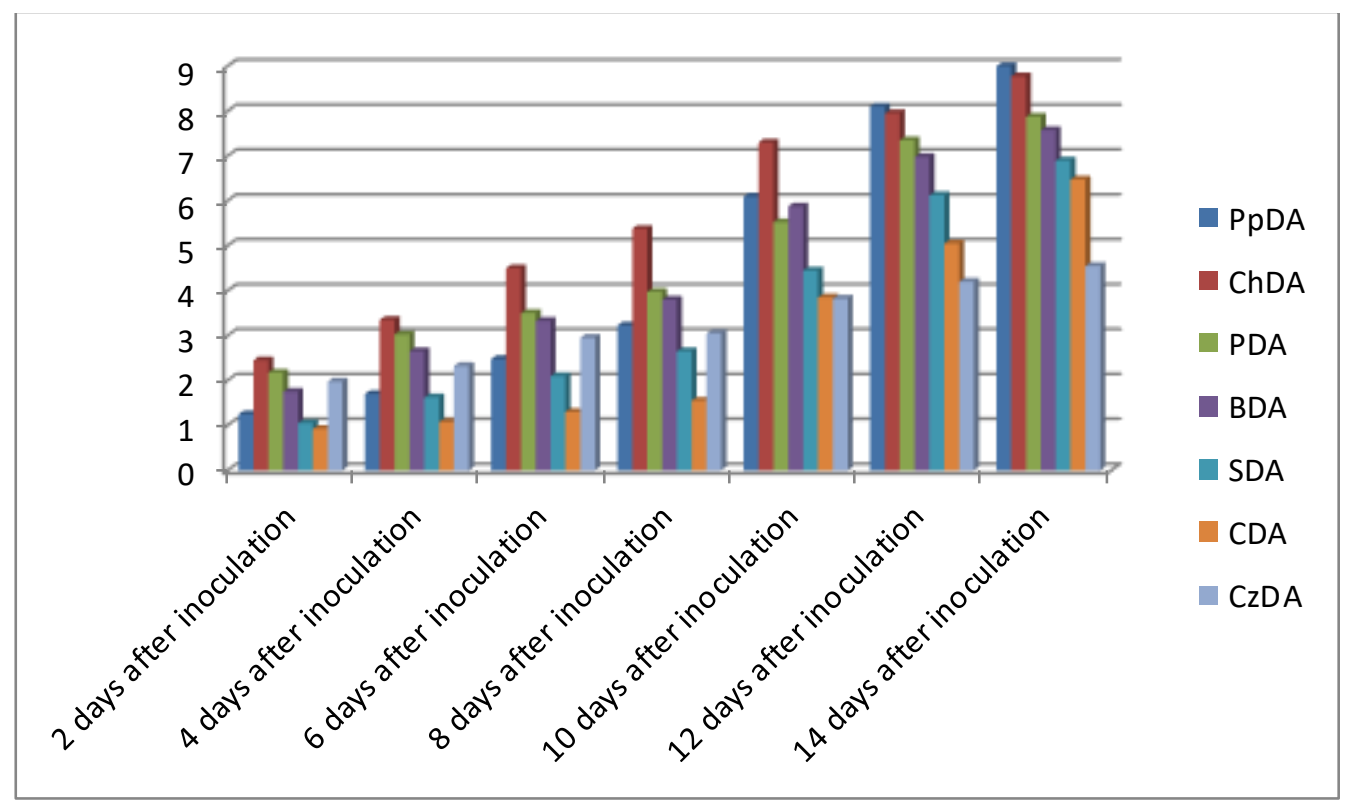

Fig.1: Mycelial growth of S. rolfsii in different culture media at various days after incubation

\section{Mycelium characteristics on different media}

The mycelium grown in chickpea dextrose agar (ChDA) had bright white color and Papaya Dextrose Agar (PpDA) had dull white color. Chickpea dextrose agar (ChDA), Bean Dextrose Agar (BDA) had condensed myceliu m whereas uncondensed in Carrot Dextrose Agar (CDA).

Table 3: Comparison of mycelium characters of S.rolfsii on different growth media

\begin{tabular}{lllll}
\hline SN & Media & Growth & Colony color & Appearance \\
\hline 1 & PpDA & Initially slowand very fast in later & dull white & Cottony dull white \\
2 & ChDA & Moderate & Bright white & Dense cottony white \\
3 & PDA & Moderate & Cottony white & Medium Cottony white \\
4 & BDA & Moderate & Light white & Condensed cottony \\
5 & SDA & Slow to moderate & Bright white & Moderately condensed \\
6 & CDA & Slow to fast & Bright white & Uncondensed cottony \\
7 & CzDA & Slow & Extra white & Wavy like, condensed at \\
& & & margins, aggregated \\
\hline
\end{tabular}




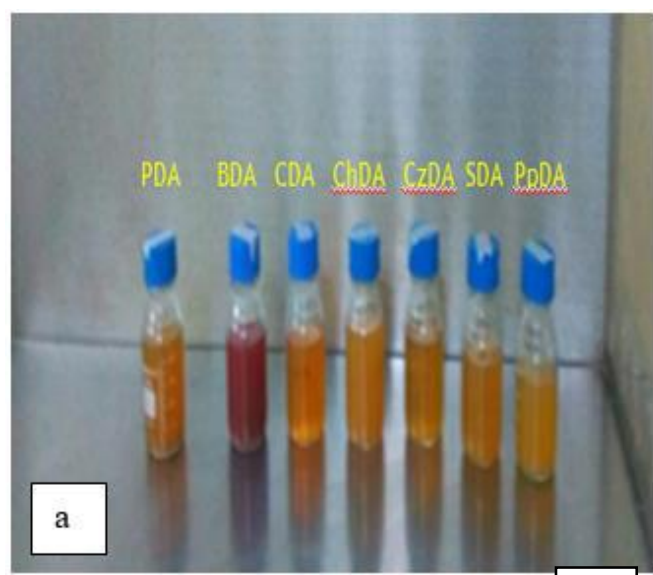

Fig.2: Preparation of culture media (a) and my b

\section{CONCLUSION}

Potato dextrose agar (PDA) is most commonly used fungal media. As an alternative to PDA, Papaya dextrose agar (PpDA), Chickpea dextrose agar (ChDA) and Bean dextrose agar (BDA) can use for the culture of sterile fungi like $S$. rolfsii, Papaya, chickpea and bean can be the cheap source of carbon for manufacturing the fungal culture media. Further study should be done to know the sporulation of fungi in these natural media.

\section{REFERENCES}

[1] Barnett, H. L., \& Hunter, B. B. (1972). Illustrated genera of imperfect fungi. Burgess Publishing Company, Minnesota.

[2] De Vay, J.E. \& H.E. Adler. 1976. Antigens common to host and parasites. Annu. Rev. Microbiol. 30: 147-168.

[3] Gurha, S.N. \& Dubey, R. S. (1982). Occurrence of possible sources of resistance in chickpea (Cicer arietinum L.) against Sclerotium rolfsiiSacc. Madras Agric.J. 70: 63-64.

[4] Jukanti, A. K., Gaur, P. M., Gowda, C. L. L., \& Chibbar, R. N. (2012). Nutritional quality and health benefits of chickpea (Cicer arietinum L.): a review. British Journal of Nutrition, 108(S1), S11-S26.

[5] KanA,Ozcelik B, Kartal M, Ozdemir ZA, Ozgen S. in vitro antimicrobial activities of Cicer arietinum L. (Chickpea). Tropical journal of Pharmaceutical Research 2010; 9(5)

[6] Mahen, V.K., Mayer, C.D., Brennemen, T.B. \& McDonald, D. (1995). Stem and pod rots of groundnut. Information Bulletin No. 4, ICRISAT, India, pp 28.

[7] Agrios GN (2004) Plant Pathology . (5thedn) San Diego, CA: Academic Press.

[8] Chan, Jr., \& Kwok, S. C. M. (1975). Importance of Enzyme Inactivation Prior to Extraction of Sugars from Papay a. Journal of Food Science, 40(4), 770-771.

[9] Gomez, M., Lajolo, F., \&Cordenunsi, B. (2006). Evolution of Soluble Sugars during Ripening of Papaya

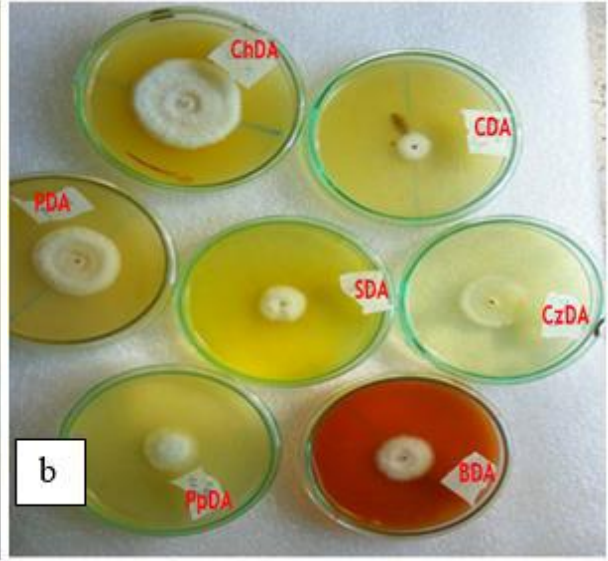

growth of S. rolfsiiin different culture media at 6 DAI

Fruit and its Relation to Sweet Taste. Journal of Food Sciences, 67(1), 442-447.

[10] Rangaswami, G., Mahadevan, A. 1999. Diseases of crop plants in India. Prentice Hall of India Pvt. Ltd., New Delhi. $6079 \mathrm{Pp}$. 